\title{
Caucalido platycarpi-Vicietum michauxii - a new weed association from crop fields of Kyrgyzstan (Middle Asia)
}

Research Article

Sylwia Nowak ${ }^{1}$, Arkadiusz Nowak ${ }^{1 *}$, Marcin Nobis², Agnieszka Nobis²

'Department of Biosystematics,

Laboratory of Geobotany and Plant Conservation,

Opole University, 45-052 Opole, Poland

${ }^{2}$ Department of Plant Taxonomy, Phytogeography and Herbarium,

Institute of Botany, Jagiellonian University,

31-501 Kraków, Poland

Received 20 March 2013; Accepted 02 September 2013

\begin{abstract}
The study presents the results of geobotanical investigations conducted in crop fields in the western Tian Shan Mts in Kyrgyzstan (Middle Asia). The main research focused on classification of weed communities developing within this poorly investigated area, were conducted in the vicinity of Bishkek and Kara-Balta in 2010. Altogether, 299 phytosociological relevés were sampled using the Braun-Blanquet method. Based on all segetal vegetation patches, the analyses distinguished a new association: Caucalido platycarpi-Vicietum michauxii. The results of these phytosociological studies fill a gap in the knowledge about the syntaxonomical diversity of the Middle Asia region, which is one of the most crucial for segetal weed species. The study shows that anthropogenic agrocoenoses could harbour relatively rich flora. Extensively cultivated fields could especially serve as a suitable habitat for many xerothermophilous and heliophilous plants. More than 75 species in vegetation plots, mainly permament weeds, have been found. There is also a considerable share of species coming over from swards, screes and meadows.
\end{abstract}

Keywords: Agrocoenoses • Vegetation ecology • Phytocoenoses • Segetal communities • Turgenio-Roemerietalia • Tian-Shan

(C) Versita Sp. z 0.0 .

\section{Introduction}

Middle Asia is a region located in the central part of the Asian continent and comprises several countries such as Kyrgyzstan, Tajikistan and Uzbekistan. In its eastern part, this is a typically mountainous area with several ranges of the Pamirian, Pamir-Alai and Tian Shan mountain systems (Figure 1). Middle Asia is also one of the richest regions as far as plant species diversity in the former Soviet Union is concerned. According to the tenvolume study of the flora of Middle Asia (Conspectus Florae Asiae Mediae) [1], more than 8,000 vascular plant species are known from the region. This number is not definitive, as recently some new species have been described from this area [2-10] and new records of its flora have been published [2,11-15]. The flora of Middle Asia is also unique. According to data from the literature on Tajikistan, approx. $30 \%$ of the entire flora of vascular plants are generally accepted endemics of the country (endemics s.str. + subendemics) [16-18]. As one of the floristically richest regions in the world, Middle Asia is threatened by a significant climate change, which could result in plant extinction and vegetation degradation [19]. Middle Asia is also regarded as the region most sensitive in the world to climate change, with the nearlowest adaptive capacity to climate instability [20].

Around the globe, research on the flora and vegetation of crop fields has been carried out within a range of contexts and with different intensity. Most studies investigate European agrocoenoses; however, several are focused on the weed vegetation of southwest Asia [21,22]. In last years several studies have been published, focusing on the problem of maintaining agrocoenoses biodiversity in relation to changes in 


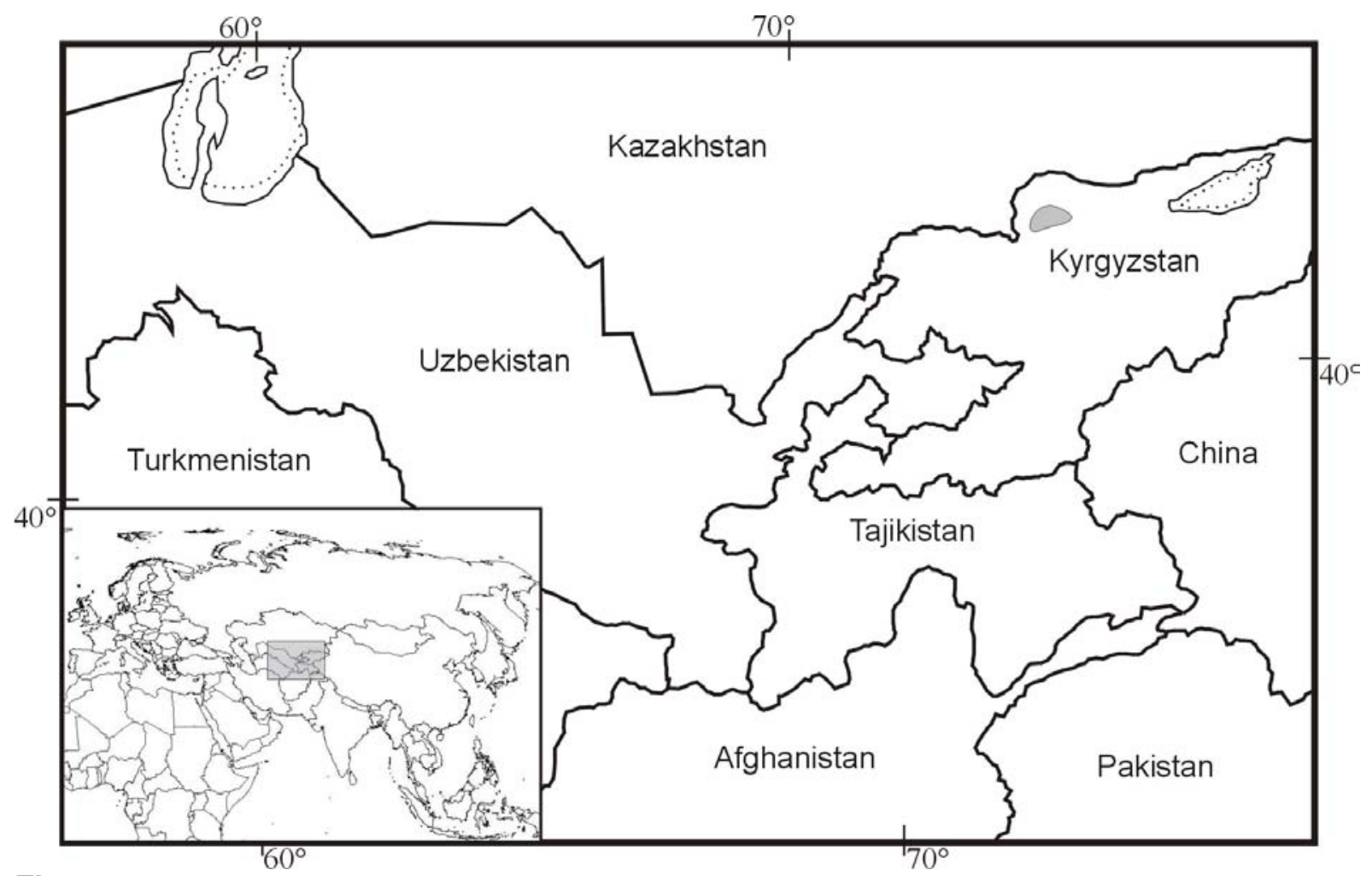

Figure 1. The area of Middle Asia with the political division and main lakes. The investigation area is highlighted with transparent grey.

intensification of crop cultivation. In Asia, as well as in Europe, in all types of plantations, a withdrawal of many field species has been noted due to intensification of agriculture or abandonment of unprofitable crops (especially in mountainous regions) $[23,24]$.

For some regions, relationships between the richness and diversity of vegetation plots, the abundance of weeds in crop phytocoenoses as well as several abiotic factors, like elevation, soil type, climate, etc., have been well studied [25-29], along with the surveys concerning the influence of different cultivation methods upon floristic composition of agrocoenoses, richness and diversity of weed communities, and also conservation value of weed flora. In most researches the implementation of modern cultivation techniques is regarded as a main responsible factor of the decreasing weed richness in field phytocoenoses [30-34].

Recently a number of surveys have documented basic records on flora and vegetation for arable field phytocoenoses, with considerable interest to their special role in the conservation of threatened or rare species [35-38]. Also, vanishing and endemic species or plant communities occurring on arable fields as ell as weed habitats other than agrocoenoses have drawn botanists attention in last years [24,39-43]. Additionally, differences in composition of field flora over the period of several years have been studied [44]. The increasing needs in weed conservation gave inspiration and involved botanists in many conservation projects focused on extinct or disappearing taxa [45]. Biological attributes of endangered species of weeds responsible for their regression [46] or expansion [47] have received less attention. Thus it is really surprising that in Middle Asia, one of the most important regions as far as the weed diversity and richness is concerned, hardly any conservation studies focused on weed flora have been conducted.

Recently, only a few papers concerning Middle Asian vegetation classification have been published [48-51], some of them relating to agrocoenoses [52,53].

Agrocoenoses in Middle Asia, probably because their extensive cultivation, are a refuge for many plant species typical for scree, riverbed and sward vegetation in this part of Asia. Abandonment or intensification of their production will probably lead, as has been noted in Europe $[23,30]$, to a decrease in biodiversity and a need for restoration programmes [45]. Therefore, there is an urgent need to document and classify the flora and vegetation of these specific agricultural ecosystems before they undergo possible degradation and impoverishment.

Syntaxonomical investigations of segetal communities have been carried out for several years in many regions of the world, mainly in countries of central Europe [54-60] and Asia [61-63]. As regards 
regions with similar macrobioclimatic conditions (Mediterranean, Irano-Turanian geobotanical provinces) useful data regarding agrocoenoses are available, e.g. for Afghanistan, Bulgaria, Greece, Italy, Romania, Serbia and Spain [64-71]. Unfortunately there is scarcity of ecological data for those weed species which reached the eastern range limit in Middle Asia and have the centers of occurrence in Saharo-Sindian province [72-74]. Unfortunately to date, in certain regions of Middle Asia, for example in Kyrgyzstan, Kazakhstan, Uzbekistan, no research of plant communities of these field ecosystems has been conducted. Phytosociological research is essential to document the syntaxonomic diversity of these specific phytocoenoses. In Middle Asia they are all the more important because so far there have been no syntaxonomic studies on segetal communities, even though the vegetation there is extremely rich and relatively well preserved due to the low intensity of cultivation. Outside Middle Asia, segetal weed vegetation studies have been conducted for a few areas situated, e.g. in Bashkortostan (southern Urals) and Mongolia in Central Asia [62,63,75].

\section{Experiments Procedures}

\subsection{Study area}

The main research was conducted in the central part of Middle Asia (Kyrgyzstan and Tajikistan) within an area approx. $350,000 \mathrm{~km}^{2}$ (Figure 1). The surveys on
Caucalido platycarpi-Vicietum michauxii were done on crop fields between Bishkek and Kara-Balta in northern Kyrgyzstan (Figure 2). This is a typically submontane area, situated at the altitude between 500 and $1,100 \mathrm{~m}$. The northern part of Middle Asia is situated generally in transition zone between the Temperate and Mediterranean macrobioclimates. According to recently published bioclimatic classification of the World, which considers mainly precipitation and temperature values, the study area has to be classified within the Mediterrenean type of macrobioclimate. This type of climate is characterized by a summer drought lasting for at least two consecutive months in which $\mathrm{P}<2 \mathrm{~T}$ [76]. In a case of Bishkek, four months in summer period match this condition (Figure 3). Also other bioclimatic features of the study area classify it to the Mediterranean macrobioclimate: The yearly average temperature is below $25^{\circ} \mathrm{C}\left(10.3^{\circ} \mathrm{C}\right)$ and the Compensated Thermicity Index is below 580 (572.3). Continentality Index is Ic=29, so our study area shows a continental type (eucontinental subtype, weak level). The Ombrotype Index $(\mathrm{lo}=2.6)$ confines the study area within the lower dry horizon. According to the thermotypes tresholds, the Bishkek region has to be classified as lower inframediterranean zone. As it is typical for the Mediterranean climate, the area has generally high solar radiation, as well as a low percentage of cloud cover, high-amplitude annual temperatures, low humidity and precipitation, with the exception of the spring period, when there is a considerable amount of rainfall (Figure 3 ). In the

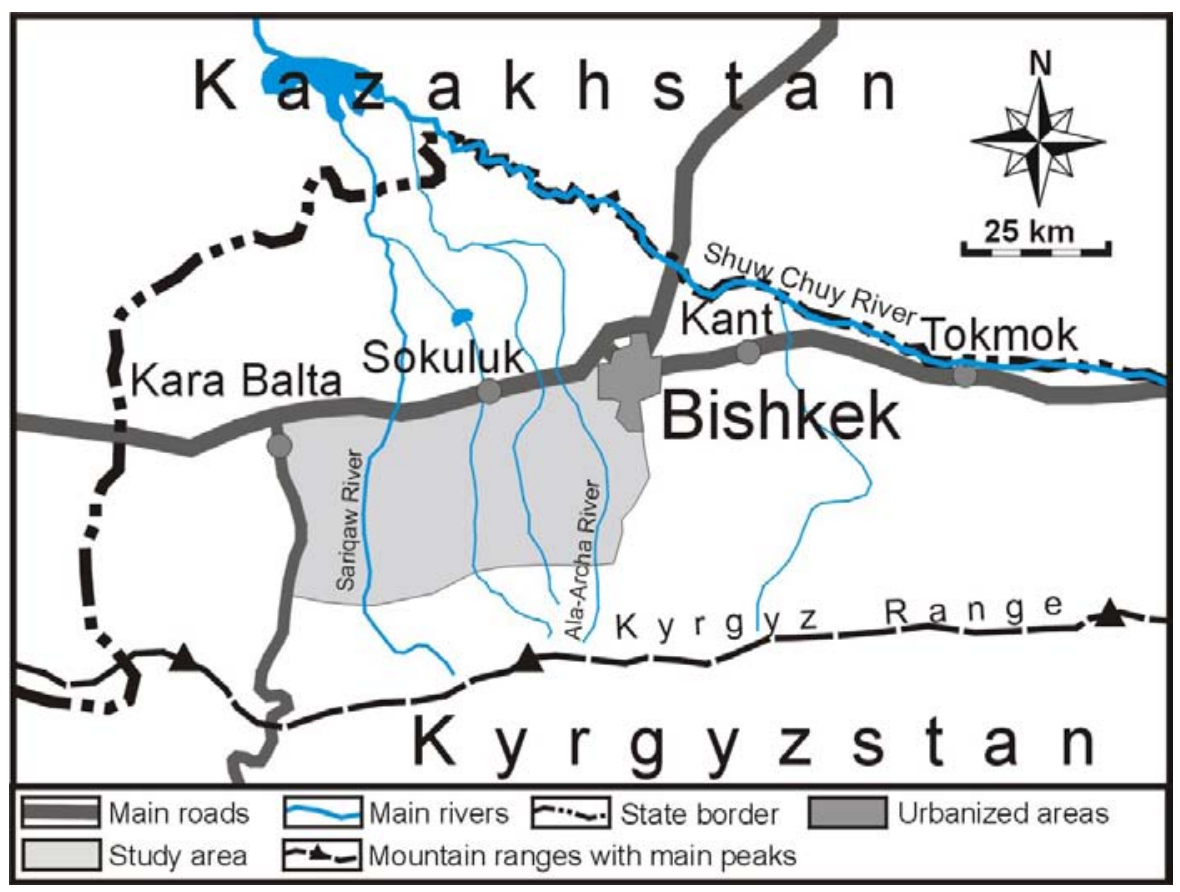

Figure 2. The schedule map of the study area with main cities, roads and rivers. 


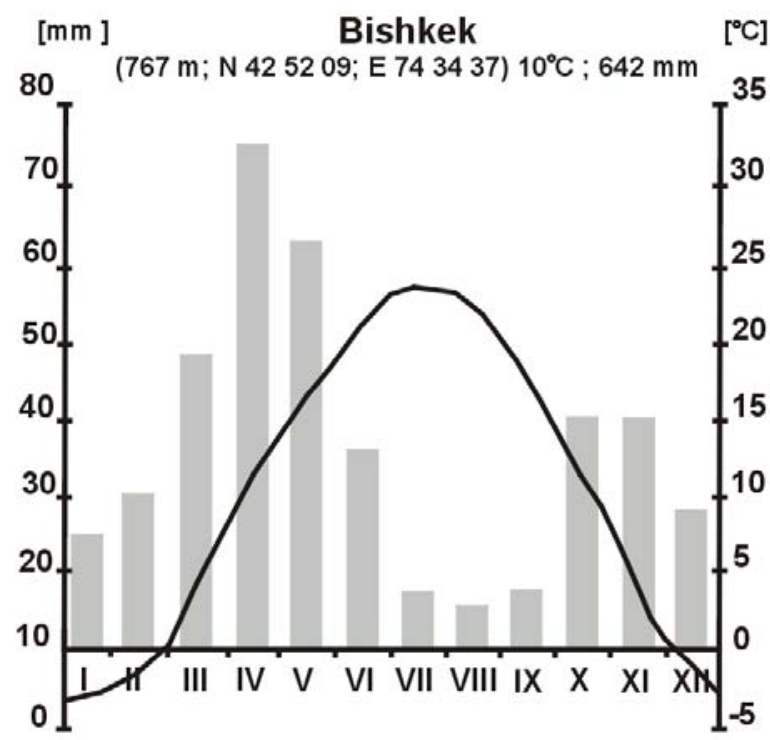

Figure 3. The climatic diagram according to the mean monthly precipitation and temperature values for Bishkek.

research area, average temperatures in June are around $22^{\circ} \mathrm{C}$. The annual precipitation here is less than $700 \mathrm{~mm}$. In the alpine zone (the high Tian Shan mountains), the climate is much harsher with average temperatures in July between 10.0 and $13.5^{\circ} \mathrm{C}$ [77]. Annual precipitation ranges here from about $500 \mathrm{~mm}$ on northern slopes to ca. 1,000 on southern. The lower limit of perpetual snow in the western Tian Shans is at an altitude of 3,000-3,300 $\mathrm{m}$ [78]. This climatic and bioclimatic terms determine the vegetation types and plant formations in the study areas, where evergreen forests and xerothermophilous swards and shrubs dominate in lowlands and in colline belt.

\subsection{Data and analyses}

During the study 299 vegetation relevés in crop fields of Middle Asia were collected between 2009 and 2012. Among these relevés, 8 samples were made in Kyrgyzstan for the association Caucalido platycarpiVicietum michauxii. The size of each vegetation relevé was $30 \mathrm{~m}^{2}$. In each them, all vascular plant species were recorded according to the cover-abundance-scale of Braun-Blanquet [79]. The seven-degree scale was used $(r,+, 1,2,3,4,5)$.

All relevés were stored in a database using the JUICE program [80]. A TWINSPAN analysis [81] and detrended correspondence analyses (DCA) were performed with the floristic data set (presence-absence data, no downweighting of rare species) to check the manual floristic-sociological classification and to illuminate the relationships between the groups. For ordination, CANOCO for Windows 4.5 was used [82]. The data from the relevés showed a clear unimodal response, enabling us to perform a Detrended Correspondence Analysis (DCA).

Vegetation classification follows the sorted table approach of Braun-Blanquet [79]. In the analytic table (Table 1), species constancies are given in constancy classes [83]. The new association was described according to the International Code of Phytosociological Nomenclature [84]. The presented association is presented in the syntaxonomical system at the end of the description. In the process of distinguishing the association, the works of Kropáč [85], Hilbig [39] and Wittig et al. [74] were taken into account.

Plant names were adopted mainly after Czerepanov [86]. Herbarium collections have been deposited in the Herbarium of Middle Asia Mountains, hosted in OPUN (Opole University, Poland).

\section{Results}

\subsection{Floristical structure of Caucalido platycarpi- Vicietum michauxii}

The number of taxa recorded in the relevés totals 75 , with 46 taxa exceeding $20 \%$ constancy and 18 taxa $60 \%$. The highest frequency was noted for several typical weeds like Vicia michauxii, V. peregrina, V. hyrcanica, Caucalis platycarpos, Roemeria refracta, Turgenia latifolia, Convolvulus arvensis and Lamium amplexicaule. Not all species noted in relevés are typical for segetal vegetation. There are many ruderal species, namely Sisymbrium irio, Descurainia sophia, Cichorium intybus, Bromus tectorum, Sisymbrium altissimum, Galium aparine, Ceratocephalus testiculatus and others as well as plants occurring mainly in scree vegetation, e.g. Dodartia orientalis, Chondrilla aspera, Filago minima, Trigonella arguata; xerothermophilous swards (Ixiolirion tataricum); or meadows and pastures (Plantago lanceolata and Hypericum perforatum). Some of the species, e.g. Lamium amplexicaule and Xanthium californicum, have come over from the neighbouring root fields. There were no observations of species restricted to wetland vegetation, e.g. rushes like Phragmites australis, Mentha asiatica, Bolboschoenus glaucus or Rorippa palustris, which occur quite often in Middle Asian crop fields due to irrigation. It is also worth noting that there was an insignificant number of neophytes within the studied vegetation patches (e.g. Galinsoga ciliata, G. parviflora).

\subsection{Numerical DCA ordination}

The Detrended Correspondence Analysis ordination run for the entire data set clearly segregates the main sample groups (Figure 4). Analysis of the habitat requirements 


\begin{tabular}{|c|c|c|c|c|c|c|c|c|c|}
\hline Successive number of releve & 1 & 2 & 3 & 4 & 5 & 6 & 7 & 8 & C \\
\hline day & 5 & 5 & 5 & 5 & 13 & 5 & 6 & 6 & 0 \\
\hline Date: month & 5 & 5 & 5 & 5 & 5 & 5 & 5 & 5 & $\mathrm{~N}$ \\
\hline year & 11 & 11 & 11 & 11 & 11 & 11 & 11 & 11 & S \\
\hline Longitude & 424,556 & 424,556 & 424,855 & 424,855 & 424,830 & 424,855 & 430,953 & 430,953 & $\mathrm{~T}$ \\
\hline Latitude & 740,177 & 740,177 & 740,285 & 740,285 & 740,256 & 740,285 & 742,389 & 742,389 & A \\
\hline Altitude (m) & 993 & 993 & 819 & 819 & 859 & 819 & 589 & 589 & N \\
\hline Cover of herb layer (\%) & 70 & 70 & 60 & 50 & 70 & 60 & 75 & 55 & C \\
\hline Releve area $\left(\mathrm{m}^{2}\right)$ & 30 & 30 & 30 & 30 & 30 & 30 & 30 & 30 & $Y$ \\
\hline $\mathrm{pH}$ & 7.1 & 7.4 & 7.8 & 7.5 & 7.5 & 7.5 & 7.3 & 7.4 & \\
\hline Number of weeds & 25 & 27 & 32 & 30 & 27 & 27 & 28 & 24 & \\
\hline \multicolumn{10}{|l|}{ Cultivated plants } \\
\hline Secale cereale & 3 & 3 & 4 & 4 & 3 & . & 2 & 3 & \\
\hline Hordeum vulgare & . & . & . & & . & 3 & & & \\
\hline \multicolumn{10}{|l|}{ ChAss. Caucalido-Vicietum } \\
\hline Vicia michauxii & + & & + & 1 & 1 & + & + & + & V \\
\hline Caucalis platycarpos & + & + & 1 & + & + & + & + & & V \\
\hline \multicolumn{10}{|c|}{ ChAll. Aveno trichophyllae-Euphorbion falcatae } \\
\hline Vicia hyrcanica & + & + & 2 & 1 & 1 & 1 & 1 & + & $\mathrm{V}$ \\
\hline Vicia peregrina & + & + & + & + & 1 & 1 & + & & $\mathrm{V}$ \\
\hline Ranunculus arvensis & 3 & 2 & 2 & 1 & 3 & + & & & IV \\
\hline Cnicus benedictus & + & + & & & + & . & . & + & III \\
\hline Heterocaryum szovitsianum & & & & & & & 2 & + & $\|$ \\
\hline Euphorbia falcata & . & . & + & & & + & & & $\|$ \\
\hline \multicolumn{10}{|c|}{ Sporadic species: Centaurea depressa 8(1). } \\
\hline \multicolumn{10}{|c|}{ ChO. Turgenio-Roemerietalia refractae } \\
\hline Roemeria refracta & 1 & 1 & . & + & + & 2 & 2 & 1 & V \\
\hline Turgenia latifolia & + & 1 & 1 & 2 & 1 & & + & 1 & V \\
\hline Galium spurium & . & + & + & + & + & & + & + & IV \\
\hline Lepyrodiclis holosteoides & & + & & + & & & + & 2 & III \\
\hline Vaccaria hispanica & . & . & 1 & + & + & . & & & $\|$ \\
\hline Vicia sativa & + & & + & + & & & & & II \\
\hline Fumaria vaillantii & & & + & & & + & & & $\|$ \\
\hline \multicolumn{10}{|c|}{$\begin{array}{l}\text { Sporadic species: Brassica campestris 6(r); Cirsium incanum 7; Galium tricornutum 5; } \\
\text { Scandix pencten-veneris 2; Sinapis arvensis } 2 \text {. }\end{array}$} \\
\hline ChCl. Stellarietea mediae & & & & & & & & & \\
\hline Convolvulus arvensis & + & 1 & + & & + & 1 & 1 & + & V \\
\hline Lamium amplexicaule & + & 1 & + & + & + & 1 & & + & V \\
\hline Veronica arguteserrata & 1 & 1 & + & 1 & + & & + & & IV \\
\hline Capsella bursa-pastoris & + & . & . & + & + & + & + & 1 & IV \\
\hline Veronica polita & & & 1 & + & + & & + & + & IV \\
\hline
\end{tabular}

Table 1. Caucalido platycarpi-Vicietum michauxii ass nova in Kyrgyzstan. 


\begin{tabular}{|c|c|c|c|c|c|c|c|c|c|}
\hline Lithospermum arvense & + & + & + & + & & & & & III \\
\hline Goldbachia torulosa & & + & & & & & 1 & + & $\|$ \\
\hline Fallopia convolvulus & . & . & + & + & + & . & . & & $\|$ \\
\hline Sisymbrium altissimum & & & + & & & + & + & & $\|$ \\
\hline Veronica persica & & & & + & + & & & + & $\|$ \\
\hline Euclidium syriacum & & & & & & & 2 & 1 & $\|$ \\
\hline Lactuca serriola & + & + & . & . & . & & . & . & $\|$ \\
\hline Lycopsis orientalis & . & . & & . & + & & + & & $\|$ \\
\hline \multicolumn{10}{|c|}{$\begin{array}{l}\text { Sporadic species: Artemisia annua 7(1); Atriplex hastata 1; Camelina sylvestris 8; } \\
\text { Cerastium perfoliatum 4; Polygonum aviculare 7; Tauscheria lasiocarpa 7(1); } \\
\text { Xanthium californicum (italicum) } 5 .\end{array}$} \\
\hline \multicolumn{10}{|l|}{ Others } \\
\hline Ceratocephalus testiculatus & 2 & 2 & + & + & 1 & 1 & 1 & 1 & v \\
\hline Litwinowia tenuissima & + & + & . & + & + & . & + & + & IV \\
\hline Thlaspi perfoliatum & & & 1 & 1 & + & 2 & & + & IV \\
\hline Alyssum desertorum & + & + & + & + & & 1 & & & IV \\
\hline Descurainia sophia & & & + & + & & $r$ & + & + & IV \\
\hline Polygonum persicaria & + & + & . & . & . & + & 1 & . & III \\
\hline Dodartia orientalis & 1 & + & . & & & + & & & $\|$ \\
\hline Cardaria repens & & . & + & + & & & & 1 & $\|$ \\
\hline Poa bulbosa & + & + & + & . & . & . & . & . & $\|$ \\
\hline Ixiolirion tataricum & + & + & . & . & . & + & . & . & $\|$ \\
\hline Viola occulta & & . & + & + & . & + & & . & $\|$ \\
\hline Stellaria neglecta & & & + & & + & & & + & $\|$ \\
\hline Veronica verna & . & & + & . & 1 & . & . & . & ॥ \\
\hline Myosotis stricta & + & & + & . & & & & . & ॥ \\
\hline Bromus tectorum & . & & + & & + & $\cdot$ & . & . & ॥ \\
\hline Arenaria serpyllifolia & . & . & + & . & . & + & . & . & ॥ \\
\hline Marrubium vulgare & & & & & & + & + & & $\|$ \\
\hline
\end{tabular}

continued Table 1. Caucalido platycarpi-Vicietum michauxii ass nova in Kyrgyzstan.

and floristic structure of these phytocoenoses shows that the factor responsible for these dissimilarities is humidity. The left part of the diagram is occupied by the relevés from the relatively driest habitats, the centre by those from relatively wet areas, and the right by the samples from the most humid areas in the highest mountainous elevations or from wetland habitats in the river valley bottoms. The vertical gradient, from the lower to the upper part of the diagram, seems to be mostly related to soil structure and the amount of gravel and sand in the soil profile. The samples located in the upper part of the biplot were taken in sandy or gravel rich soils. Caucalido platycarpi-Vicietum michauxii is a relatively well-distinguished association and occupies the uppercentral part of the diagram, where samples typical for relatively fertile and moisture (fresh) soils and medium elevations (mainly between 800 to $1,000 \mathrm{~m}$ a.s.l.) are concentrated. The reason for the distinctiveness of these central phytocoenoses' patches revealed by the correspondence analyses is, of course, essential differences in floristic composition and structure.

\subsection{Description of Caucalido platycarpi- Vicietum michauxil ass. nova \\ Diagnostic species: Vicia michauxii, Caucalis platycarpos}

This association prefers relatively low altitudes, mostly between 600 and $900 \mathrm{~m}$. Patches of the phytocoenoses were found on the foothills, gently falling to the north, of the Tian-Shan range. It develops on loose, clayey, alkaline, 


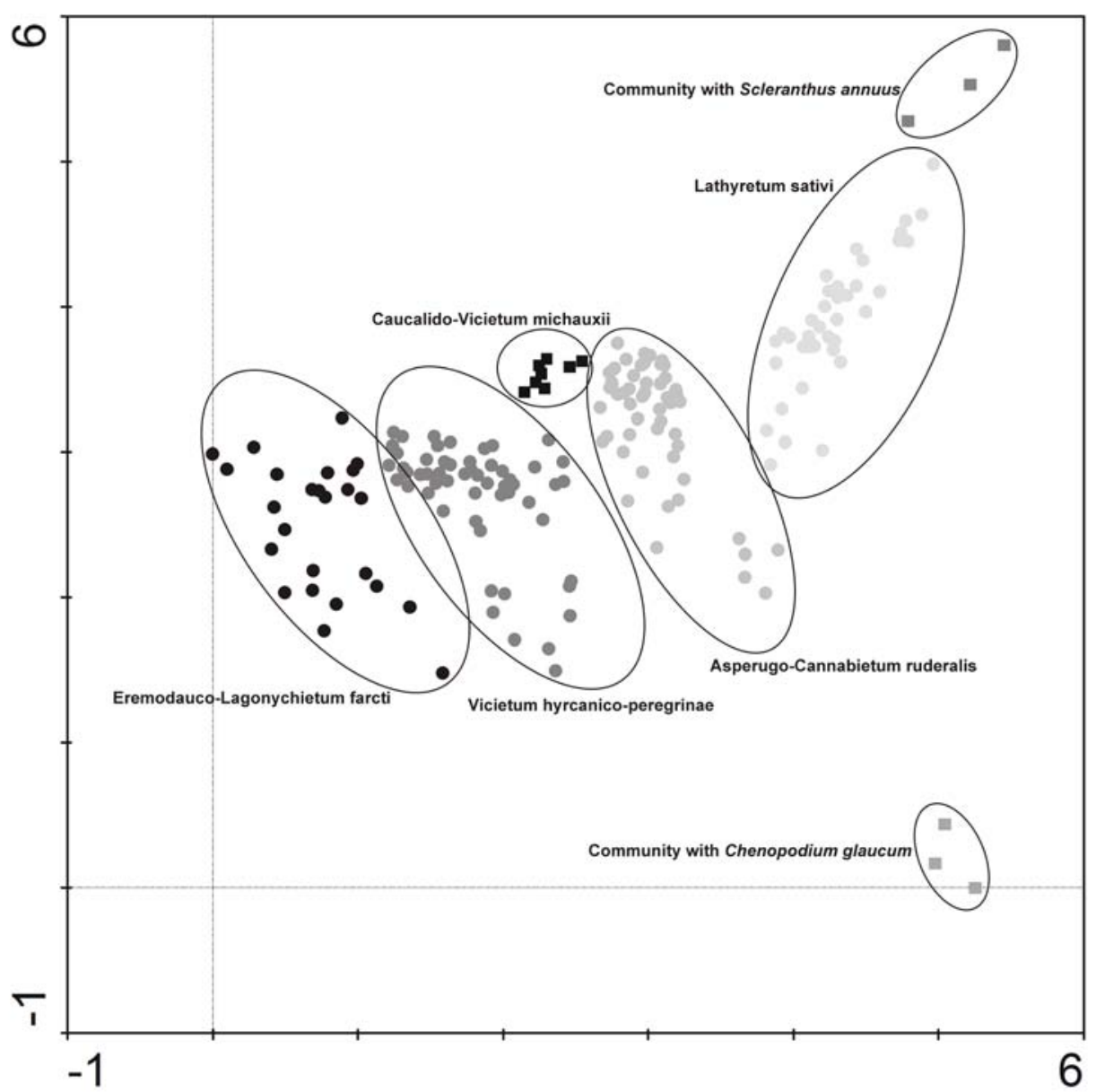

Figure 4. DCA ordination for all samples $(\mathrm{N}=299)$ with indication of Caucalido platycarpi-Vicietum michauxii $(\mathbf{m})$ on the background of other samples of other segetal phytocoenoses known from Middle Asia.

fertile and fresh soils and is relatively rich in species. In a single patch, between 25 and 32 taxa were noted. The average number of species per relevé is 28 . The total cover value of weed species in the phytocoenoses does not exceed $65 \%$, and, in most cases, was ca. $35-40 \%$. Among the most constant and frequently contributing species are: Vicia michauxii, Caucalis platycarpos, Vicia hyrcanica, Thlaspi perfoliatum, Litvinovia tenuissima, Vicia peregrina, Ixiolirion tataricum, Alyssum desertorum and Ranunculus arvensis. Both main diagnostic species belong to the rarest elements of Middle Asian flora; consequently, the association is likewise rather infrequent. Because the range of the diagnostic species (especially Vicia michauxii) is much larger than northern Kyrgyzstan, it is supposed that the association is also present in other regions of Middle Asia, e.g. Tajikistan [87].

\subsection{Syntaxonomical position of the association} The plots of Caucalido-Vicietum association appears exclusively on crop fields in central part of Middle Asia which determines its syntaxonomical position within the Stellarietea mediae class.

Class: Stellarietea mediae Tüxen et al. ex von Rochov 1951

Ord.: Turgenio latifoliae-Roemerietalia refractae S. Nowak et al. 2013

All: Aveno trichophyllae-Euphorbion falcatae S. Nowak et al. 2013

Ass.: Caucalido platycarpi-Vicietum michauxii ass. nova (holotypus hoc loco Table 1, rel. 4)

\section{Discussion}

Being one of the world's richest regions in flora, Middle Asia should also have a significant number of weed species along with their communities. Surprisingly, despite being so rich in weed species, the Middle Asia has not drawn considerable attention of botanists so far, and only few studies concerning segetal flora 
have been published for that region long time ago [e.g. 88]. To find out research needs for agrocoenoses and delimit the most interesting study areas in Middle Asia, a reconnaissance studies and a herbarium and literature query were conducted by authors in the years 2008-2011. We found out that even for relatively small areas, e.g. Tajikistan, the segetal flora consists of almost 700 taxa. The most weed-rich regions of Middle Asia are the southwestern areas of Tajikistan and central part of the region - the Fergana Valley where over 500 species have been observed [89]. Relatively rich in species are also the plots of Caucalido-Vicietum from northern Kyrgyzstan. Despite their location on the outskirts of a warm mediterranean climate zone, samples with more than 30 species have to be regarded as significantly rich in segetal species when compared to other crop cultivation areas in the world [e.g. 21,22,25,39,58,60,71,90].

The specificity of soil substrate (gravel-sandy soils and alkaline $\mathrm{pH}$ ) and the floristic structure of the community patches clearly separate the CaucalidoVicietum samples from other segetal vegetation plots (see Figure 4). After recent phytosociological studies completed in Tajikistan [53] the position of the association within the syntaxonomical system is quite clear. Due to the considerable differences between the dominant species of the Middle Asian and European crop communities, a new vegetation order and alliance were proposed (Turgenio latifoliae-Roemerietalia refractae and Aveno trichophyllae-Euphorbion falcatae). Most species making up the described community originated from Middle Asia or the Irano-Turanian phytogeographical province, with only a few coming from the Eurosiberian range. As diagnostic for the order, taxa relatively often occurring in cereals, Turgenia latifolia and Roemeria refracta, have been chosen (Table 1). Within the order, the alliance of Aveno trichophyllae-Euphorbion falcatae was singled out. This includes the phytocoenoses of warm places on alkaline substrates in Middle Asia, influenced by a mediterranean or submediterranean climate. Species proposed as diagnostic for this alliance are Vicia hyrcanica, V. peregrina, Ranunculus arvensis, Cnicus benedictus, Heterocaryum szovitsianum and Euphorbia falcata. All of these species, occurring with high constancy and relatively significant abundance, have built up the community and distinguished it from the geographical vicariant Caucalido-Scandicetum from Europe and northwestern Asia [25,53,57,59,60]. Obviously, the final syntaxonomical classification of the segetal communities of Middle Asia requires further phytosociological studies.

Analyses of the chorology of the main diagnostic species for the association show that the potential range of Caucalido platycarpi-Vicietum michauxii includes the area of central and northern Tajikistan, eastern Uzbekistan and southern Kyrgyzstan as well as the northern limits of the Irano-Turanian and Mediterranean provinces. The suitable climate and alkaline soils within the great river valleys, with considerable amounts of gravel and sand, could harbour Caucalido platycarpi-Vicietum michauxii in many sites. However, until now, despite the penetration of many areas (e.g. in Uzbekistan, Tajikistan and Kyrgyzstan), phytocoenoses of Caucalido platycarpi-Vicietum michauxii have not been found. It is supposed that Vicia michauxii as the main diagnostic species of the association, due to the intensification of cultivation methods, is under significant anthropogenic pressure in Middle Asia.

\section{Acknowledgements}

The authors wish to thank Prof. Giorgij Lazkov from the Kyrgyz Academy of Sciences for assistance in field works and help in species determination. The project was partially funded by the Polish Ministry of Science, grant No N304 377838/2010.

\section{References}

[1] Kovalevskaya S.S., Opredelitel rastenii Srednej Azii. Vol. I-X. Akademia Nauk USSR, Izdatelstvo "FAN" Uzbekskoi SSR, Tashkent, 1968

[2] Lazkov G.A., Sultanova B.A., Checklist of vascular plants of Kyrgyzstan, Norrlinia, 2011, 24, 1-166

[3] Nobis M., Stipa adamii sp. nov. (Poaceae) from the western Tian-Shan, and some remarks on the taxa of the section Smirnovia occurring in Kazakhstan. Nord. J. Bot., 2010, 28(6), 728-733

[4] Fritsch R.M., Khassanov F.O., Matin F., New Allium taxa from Middle Asia and Iran, Stapfia, 2002, 80, 381-393
[5] Khassanov F.O., Shomuradov H., Tobaev K., A new Allium L. species from Middle Asia. Linzer Biologische Beitrage, 2007, 39(2), 799-802

[6] Fritsch R.M., Friesen N., Allium oreotadzhikorum and Allium vallivanchense, two new species of Allium subg. Polyprason (Alliaceae) from the Central Asian republic Tajikistan, Feddes Repert, 2009, 120(3-4), 221-231

[7] Sennikov A., Lazkov G., Allium formosum Sennikov \& Lazkov (Amaryllidaceae), a new species from Kyrgyzstan, PhytoKeys, 2013, 21, 29-36 
[8] Nobis M., Stipa xbrozhiana (Poaceae) nothosp. nov. from the western Pamir Alai Mts (middle Asia) and taxonomical notes on Stipaxtzvelevii, Nord. J. Bot., 2011b, 29, 458-464

[9] Nobis M., Stipa narynica sp. nov. (Poaceae) from the Western Tian-Shan Mountains, Nord. J. Bot., 2011, 30, 70-76

[10] Nobis M., Taxonomic revision of the Stipa lipskyi group (Poaceae: Stipa section Smirnovia) in the Pamir Alai and Tian-Shan Mountains, Plant Syst. Evol., 2013, 299 (in print), Doi: 10.1007/s00606013-0799-5

[11] Lazkov G., Gastrolychnis alexeenkoi Lazkov (Caryophyllaceae) - a new species to the flora of Tajikistan, Novosti Sistematiki Vysshih Rastenii, 2008, 20, 68-69

[12] Nobis M., Nowak A., Zalewska-Gałosz J., Potamogeton pusillus agg. in Tajikistan (Middle Asia), Acta Soc Bot Pol, 2010, 79(3), 235-238

[13] Nobis M., Remarks on the taxonomy and nomenclature of the Stipa tianschanica complex (Poaceae), on the base of a new record for the flora of Tajikistan (central Asia), Nord. J. Bot., 2011a, 29, 194-199

[14] Nobis M., Nowak A., New data to the vascular flora of the central Pamir Alai Mountains (Tajikistan, middle Asia), Pol. B. J., 2011a, 56(2), 195-201

[15] Nobis M., Nowak A., New data to the vascular flora of the central Pamir Alai Mountains (Tajikistan, Central Asia), Part II, Časopis SZM (A), 2011b, 60, 259-262

[16] Rasulova M.R., Flora Tadzhikskoi SSR. 10, Slozhnotsvetnye, Izdatelstvo Nauka, Leningrad, 1991

[17] Nowak A., Nobis M., Tentative list of endemic vascular plants of Zeravshan Mts in Tajikistan (Middle Asia): distribution, habitat preferences and conservation status of species, Biodiv. Res. Conserv., 2010, 19, 65-80

[18] Nowak A., Nowak S., Nobis M., Distribution patterns, ecological characteristic and conservation status of endemic plants of Tadzhikistan - A global hotspot of diversity, J. Nat. Conserv., 2011, 19, 296-305

[19] Baettig R.B., Wild M.M., Imboden D.M., A climate change index: Where climate change may be most prominent in the 21st century, Geophys. Res. Lett., 2007, 34, 457-469

[20] Fay M., Patel H., A simple index of vulnerability to climate change. Background paper prepared for World Bank report. Washington, DC, 2008

[21] Gomaa N.H., Composition and diversity of weed communities in Al-Jouf province, northern Saudi Arabia. Saudi. J. Biol. Sci., 2012, 19, 369-376
[22] Rassam G., Latifi N., Soltani A., Kamkar B., Impact of crop management on weed species diversity and community composition of winter wheat fields in Iran, Weed Biol. Manag., 2011, 11, 83-90

[23] Robinson R.A., Sutherland W.J., Post-war changes in arable farming and biodiversity in Great Britain, J. Appl. Ecol., 2002, 39, 157-176

[24] Türe C., Böcük H., Investigation of threatened arable weeds and their conservation status in Turkey, Weed Res., 2008, 48, 289-296

[25] Lososová Z., Chytrý M., Cimalová S., Kropáč Z., Otýpková Z., Pyšek P., et al., Weed vegetation of arable land in Central Europe: gradients of diversity and species composition, J. Veg. Sci., 2004, 15, 415-422

[26] Pyšek P., Jarošik V., Kropáč Z., Chytrý M., Wild J., Tichý L., Effects of abiotic factors on species richness and cover in Central European weed communities, Agr. Ecosyst. Environ., 2005, 109, 1-8

[27] Fried G., Norton L.R., Reboud X., Environmental and management factors determining weed species composition and diversity in France, Agr. Ecosyst. Environ., 2008, 128, 68-76

[28] Lososová Z., Chytrý M., Kühn I., Plant attributes determining the regional abundance of weeds on central European arable land, J. Biogeogr, 2008, 35, 177-187

[29] Cimalová Š., Lososová Z., Arable weed vegetation of the northeastern part of the Czech Republic: effects of environmental factors on species composition, Plant Ecol., 2009, 203, 45-57

[30] Hyvönen T., Salonen J., Weed species diversity and community composition in cropping practices at two intensity levels - a six year experiment, Plant Ecol., 2002, 154, 73-81

[31] Gerowitt B., Bertke E., Hespelt S.-K., Tute C., Towards multifunctional agriculture - weeds as ecological goods?, Weed Res., 2003, 43, 227-235

[32] Storkey J., A functional group approach to the management of UK arable weeds to support biological diversity, Weed Res., 2006, 46, 513-522

[33] Lososová Z., Cimalová S., Effectis of different cultivation types on native and alien weed species richness and diversity in Moravia, Basic Appl. Ecol., 2009, 10, 456-465

[34] Pinke G., Pál R., Botta-Dukát Z., Chytrý M., Weed vegetation and its conservation value in three management systems of Hungarian winter cereals on base-rich soils, Weed Res., 2009, 49, 544-551

[35] Barrett S.C.H., Seaman D.E., The weed flora of californian rice fields, Aquat. Bot., 1980, 9, 351-376 
[36] Camenisch M., Cook C.D.K., Wiesneria triandra (Dalzell) Micheli (Alismataceae): a rare and unusual south Indian endemic, Aquat. Bot., 1996, 55, 115131

[37] Turki Z., Sheded M., Some observations on the weed flora of rice fields in the Nile Delta, Egypt, Feddes Repert, 2002, 5-6, 394-403

[38] Freemark K.E., Boutin C., Keddy C.J., Importance of farmland habitats for conservation of plant species, Conserv. Biol., 2001, 16(2), 339-412

[39] Hilbig W., Protection and conservation of endangered species and its Segetalvegetation (arable wild plant protection) [Schutz und Erhaltung der Segetalvegetation und ihrer gefährdeten Arten (Ackerwildpflanzenschutz)], Feddes Repert, 2002, 113(5-6), 404-421 (in German)

[40] Warcholińska A.U., Threatened segetal flora species of the Łódź heights, Biodiv. Res. Conserv, 2006, 3-4, 391-394

[41] Storkey J., Westbury D.B., Mini-Review Managing arable weeds for biodiversity, Pest. Manag. Sci., 2007, 63, 517-523

[42] Romero A.L., Chamorro L., Sans F.X., Weed diversity in crop edges and inner fields of organic and conventional dryland winter cereal crops in NE Spain, Agr. Ecosyst. Environ., 2008, 124, 97-104

[43] Van Calster H., Vandenberghe R., Ruysen M., Verheyen K., Hermy M., Decocq G., Unexpectedly high 20th century floristic losses in a rural landscape in northern France, J. Ecol., 2008, 96, 927-936

[44] Sutcliffe O.L., Kay Q.O.N., Changes in the arable flora of central southern England since the 1960s, Biol. Conserv., 2000, 93, 1-8

[45] Kohler F., Vandenberghe C., Imstepf R., Gillet F., Restoration of Threatened Arable Weed Communities in Abandoned Mountainous Crop Fields, Restor. Ecol., 2010, 11, 15-23

[46] Gibson R.H., Nelson I.L., Hopkins G.W., Hamlett B.J., Memmott J., Pollinator webs, plant communities and the conservation of rare plants: arable weeds as a case study, J. Appl. Ecol., 2006, 43, 246-257

[47] Melander B., Holst N., Grundy A.C., Kempenaar C., Riemens M.M., Verschwele A., et al., Weed occurrence on pavements in five north European towns, Weed Res., 2009, 49, 516-525

[48] Nowak A., Nobis M., Distribution patterns, floristic structure and habitat requirements of the alpine river plant community Stuckenietum amblyphyllae ass. nova (Potametea) in the Pamir Alai Mountains (Tajikistan), Acta. Soc. Bot. Pol., 2011, 80(3), 235-238

[49] Nowak A., Nobis M., Distribution, floristic structure and habitat requirements of the riparian forest community Populetum talassicae ass. nova in the
Central Pamir-Alai Mts (Tajikistan, Middle Asia), Acta. Soc. Bot. Pol., 2013, 82(1), 47-55

[50] Nobis M., Nowak A., Nobis A., Stipa zeravshanica (Poaceae) a new endemic species from rocky walls of the western Pamir Alai Mountains (Tajikistan, middle Asia): taxonomy, distribution and habitat ecology, Nord. J. Bot., 2013 (in print; doi: 10.1111/j.17651051.2013.00184.x)

[51] Nowak S., Nowak A., Weed communities of root crops in the Pamir Alai Mts, Tajikistan (Middle Asia), Acta. Soc. Bot. Pol., 2013, 82(2), 135-146

[52] Nowak S., Nowak A., Nobis M., Weed communities of rice fields in the central Pamir Alai Mountains (Tajikistan, Middle Asia), Phytocoenologia, 2013, 43(1-2), 101-126

[53] Nowak S., Nowak A., Nobis M., Nobis A., Weed vegetation of cereal crops in Tajikistan (Pamir Alai Mts, Middle Asia), Phytocoenologia, 2013, 43(3), (in print; doi: 10.1127/0340-269X/2013/0043-0557)

[54] Pott R., Plant communities of Germany [Die Pflanzengesellschaften Deutschlands], 2 Aufl, Verlag Eugen Ulmer, Stuttgart, 1995 (in German)

[55] Schubert R., Hilbig W., Klotz S., A guide to the identification of plant communities of Central and Northern Germany [Bestimmungsbuch der Pflanzengesellschaften Mittel- und Nordostdeutschlands], G. Fischer, Jena - Stuttgart, 1995 (in German)

[56] Matuszkiewicz W., A guide to identification of plant communities of Poland [Przewodnik do oznaczania zbiorowisk roślinnych Polski], Wydawnictwo Naukowe PWN, Warszawa, 2007 (in Polish)

[57] Lososová Z., Weed vegetation in southern Moravia (Czech Republic): a formalized phytosociological classification, Preslia, 2004, 76, 65-85

[58] Lososová Z., Chytrý M., Cimalová S., Otýpková Z., Pyšek P., Tichý L., Classification of weed vegetation of arable land in the Czech republic and Slovakia, Folia Geobot., 2006, 41, 259-273

[59] Šilc U., Čarni A., Formalized classification of the weed vegetation of arable land in Slovenia, Preslia, 2007, 79, 283-302

[60] Kropáč Z., Mochnacký S., Contribution to the segetal communities of Slovakia, Thaiszia - J. Bot., 2009, 19, 145-211

[61] Sádlo J., Kolbek J., The terrestrial ruderal and segetal vegetation of North Korea: a synthesis, Folia Geobot. Phytotx., 1997, 32, 25-40

[62] Yamalov S.M., Martynenko W.B., Golub W.B., Baisheva E.Z., Prodromus of plant communities of the Republic of Bashkortostan [Prodromus rastitelnych ssobshchestv respubliki Bashkortostan], Akademia Nauk Rasii, Ufa, 2004 (in Russian) 
[63] Yamalov S.M., Shaikhislamova E.F., Mirkin B.M., The segetal vegetation of Bashkirian Transural, Rastitelost Rasii., 2007, 10, 89-99

[64] Gilli A., The ruderal and segetal vegetation of Afghanistan [Afghanische Ruderal- und Segetalgesellschaften], Feddes Repert, 1975, 86(3), 171-197 (in German)

[65] Bergmeier E., The diversity of segetal weeds in Crete (Greece) at species and community level, Ann. Bot., 2006, 6, 53-64

[66] Brullo S., del Galdo G.G., Guarino R., Minissale P., Spampinato G., A survey of the weedy communities of Sicily, Ann. Bot., 2007, 7, 127-161

[67] Zamora J., Verdu J.R., Galante E., Species richness in Mediterranean agroecosystems: Spatial and temporal analysis for biodiversity conservation, Biol. Conserv., 2007, 134, 113-121

[68] Sanda V., Öllerer K., Burescu P., Phytocoenoses of Romania [Fitocenozele din România], Ars Docendi, Universitatea din Bucuresti, Bucuresti, 2008 (in Romanian)

[69] Vrbnicanin S., Stevanovic Z.D., Radovanov K.J., Uludağ A., Weed vegetation of small grain crops in Serbia: environmental and human impacts, Turk. J. Agric. For., 2009, 33, 325-337

[70] Šilc U., Vrbnicanin S., Božić D., Čarni A., Stevanovic A., Weed vegetation in the north-western Balkans: diversity and species composition, Weed Res., 2009, 49, 602-612

[71] Tzonev R.T., Dimitrov M.A., Roussakova V.H., Syntaxa according to the Braun-Blanquet approach in Bulgaria, Phytol. Balcan., 2009, 15(2), 209-233

[72] Tamado T., Milberg P., Weed flora in arable fields of Eastern Ethiiopia with emphasis on the occurrence of Parthenium hysterophorus, Weed Res., 2000, 40, 507-521

[73] Karar R.O., Mohamed B.F., Marrs R.H., Factors influencing the weed flora in the Gezira Scheme, Sudan, Weed Res., 2004, 45, 121-129

[74] Wittig R., Becker U., Ataholo M., Weed communities of arable fields in the Sudanian and the Sahelian zone of West Africa, Phytocoenologia, 2011, 41(2), 107-141

[75] Hilbig W., Bumzaa D., The segetal vegetation of the Mongolian Republic [Die Ackerunkrautvegetation der Mongolischen Volksrepublik], Archivum für Naturchutz und Landschaftforschung, 1985, 25, 1932 (in German)

[76] Rivas-Martínez S., Rivas-Sáenz S., Merino A.P., Worldwide Bioclimatic Classification System, Global Geobotany, 2011, 1, 1-638

[77] Narzikulov I.K., Stanjukovich K.W., Atlas of the Tajik's Soviet Socialist Republic [Atlas Tajikskoi SSR],
Akademia Nauk Tajikskoi SSR, Dushanbe-Moskva, 1968 (in Russian)

[78] Latipova W.A., Kolichestvo osadkov. 68-69, [In:] Narzikulov IK \& Stanjukovich KW (eds), Atlas Tajikskoi SSR. Akademia Nauk Tajikskoi SSr, DushanbeMoskva, 1968

[79] Braun-Blanquet J., Phytosociology [Pflanzensoziologie], Grundzüge der Vegetationskunde, Springer, Wien, 1964 (in German)

[80] Tichý L., JUICE, software for vegetation classification, J. Veg. Sci., 2002, 13, $451-453$

[81] Hill M.O., TWINSPAN - A FORTRAN program for arranging multivariate data in an ordered two-way table by classifi cation of the individuals and attributes. Ecology and Systematics, Cornell University, Ithaca, New York, USA, 1979

[82] Ter Braak C.J.F., Šmilauer P., CANOCO Reference Manual and CanoDraw for Windows User's guide: Software for Canonical Community Ordination (version 4.5), Microcomputer Power, Ithaca, New York, USA, 2002

[83] Dierschke H., Phytosociology [Pflanzensoziologie], Ulmer Verlag, Stuttgart, 1994 (in German)

[84] Weber H.E., Moravec J., Theurillat J.P., International code of Phytosociological Nomenclature, 3rd edition, J. Veg. Sci., 2000, 11, 739-768

[85] Kropáč Z., Segetal vegetation in the Czech Republic: synthesis and syntaxonomical revision, Preslia, 2006, 78, 123-209

[86] Czerepanov S.K., Plantae Vasculares URSS. Nauka, Leningrad, 1995

[87] Nowak S., Nowak A., Nobis M., Nobis A., Vicio michauxii-Caucalidetum platycarpi - a new plant association from Kyrgyzstan. 1st Int. Conf. "Biodiversity \& Nature Conservation in the Middle \& Central Asia. Ostrava, Czech Republic, 2012, 14

[88] Wasilchenko I.T., Crop field vegetation of Tajikistan [Sornyje rastienia Tadżykistana], Izdatelstwo Akademii Nauk SSSR, Moskwa-Leningrad, 1953 (in Russian)

[89] Nowak A., Nowak S., The diversity and chorology of segetal weeds in the gradientaltitude mountains of Pamir-Alajuela in Tajikistan. 1st national conferenceon "Synanthropization a changing diversitybiological" [Zróżnicowanie i chorologia chwastów segetalnych w gradiencie wysokościowym gór Pamiro-Ałaju w Tadżykistanie. I ogólnopolska konferencja naukowa "Synantropizacja w dobie zmian różnorodności biologicznej”], Wrocław, Poland, 2011, 29 (in Polish)

[90] Fried G., Petit S., Dessaint F., Reboud X., Arable weed decline in Northern France: Crop edges as refugia for weed conservation?, Biol Conserv, 2009, 142, 238-243 